\title{
FIRST REPORT OF Begomovirus INFECTION ON PAPAYA IN BENGKULU, INDONESIA
}

\section{Mimi Sutrawati ${ }^{1}$, Parwito ${ }^{2}$, Priyatiningsih ${ }^{1}$, Agustin Zarkani ${ }^{1}$, Sipriyadi ${ }^{3}$, Yenny Sariasih ${ }^{1}$, \& Dwi Wahyuni Ganefianti ${ }^{4}$}

\author{
${ }^{1}$ Study Program of Plant Protection, Faculty of Agriculture, University of Bengkulu, Indonesia \\ Jl. WR Supratman, Kandang Limun Bengkulu 38371 \\ ${ }^{2}$ Departement of Agrotechnology, Faculty of Agriculture, Universitas Ratu Samban, Indonesia \\ Jl. Jend. Sudirman, No 87 Arga Makmur, Bengkulu Utara, Bengkulu 38611 \\ ${ }^{3}$ Study Program of Biology, Faculty of Mathematics and Natural Sciences, University of Bengkulu, Indonesia \\ Jl. WR Supratman, Kandang Limun Bengkulu 38371 \\ ${ }^{4}$ Study Program of Agroecotechnology, Faculty of Agriculture, University of Bengkulu, Indonesia \\ Jl. WR Supratman, Kandang Limun Bengkulu 38371 \\ Email:parwito@fdi.or.id
}

Manuscript received: 12 July 2020. Revision accepted: 19 January 2021.

\begin{abstract}
First report of Begomovirus infection on papaya in Bengkulu, Indonesia. A field survey was conducted during 2019, we found a severe systemic yellow mosaic, striped green mosaic on leaves petiole, green spots on the fruit of papaya, leaf malformation, and stunting symptoms on three papaya cultivation area in Rejang Lebong, Kepahiang, Bengkulu Tengah, and Seluma, Bengkulu Province, Indonesia. A begomo-like virus was inferred to be the possible cause of the virus-disease-like symptoms. The study aimed to identify the causal of those typical symptoms on papaya. PCR using universal primer for transcriptional activator protein $(\operatorname{Tr} A p)$ and replication-associated protein $(R e p)$ gene of Begomovirus successfully amplified the DNA fragments of $900 \mathrm{bp}$ in all 10 detected samples, except for samples with leaf malformation and stunting symptoms. It is indicating that those typical symptoms on papaya is associated with Begomovirus infection, while the causal of leaf malformation and stunting is unknown yet. This work is the first report of Begomovirus infected papaya in Indonesia. Severe disease incidence caused by this pathogen was observed on papaya plants in Bengkulu Province that was in the range of 42 $100 \%$. This finding is a precious information to be used for identification, and characterization the species of the virus, determining control strategies against the disease.
\end{abstract}

Key words: leaf malformation, polymerase chain reaction, stunting, yellow mosaic

\section{INTRODUCTION}

Papaya (Carica papaya) is one of the important fruit and widely cultivated in Indonesia. At least 20 plant viruses species have emerged in tropical and subtropical regions infecting papaya (Tennant et al., 2007). The severity of disease symptoms varies widely from mild to severe; reducing plant vigor, yield, and impaired fruit quality. Numerous Begomovirus and Potyvirus have been characterised from papaya in India. The study of Papaya leaf curl virus (PalCV) was reported in 1998 (Saxena et al., 1998). Another reports of Begomovirus infecting papaya i.e. Papaya leaf crumple virus (PalCrV), Chilli leaf curl virus (ChilCuV), Tomato leaf curl New Delhi virus (ToLCuNDV), Croton yellow vein mosaic virus (CYVMV) (Chang et al., 2003; Singh-Pant et al., 2012) have been documented.
There have not been many reports about diseases caused by viral infections in papaya plants in Indonesia. Previously, the causal of ringspot disease on papaya by Papaya ring spot virus strain P (PRSV-P) have been reported in Indonesia. First report of PRSV infection on papaya in Nanggroe Aceh Darussalam Province (Hidayat et al., 2012). It was also reported in Medan, Bogor, and Bali, with disease incidence reaching 100\% (Hidayat et al., 2013; Harmiyati et al., 2015; Nuhantoro et al., 2017). Furthermore, Listihani et al. (2018) reported the present of PRSV-P on cucumbers in Java.

The diseased papaya leaves found in Bengkulu was different to those found in other area in Indonesia. During field survey in January to October 2019 at seven papaya cultivation areas in 4 districts in Bengkulu Province (Figure 1), we found a systemic symptom of yellow mosaic, upward leaf curling, and stunting, dark 
green and light green striped mosaic patterns on the petiole, and green spots on papaya fruit in almost all locations. The symptoms were typically caused by plant pathogenic viruses. The symptom found on papaya leaves in Bengkulu showed severe mosaic with a distinctive yellow color indicating that it may caused by different virus(es). The study aimed to identify the causal virus of severe yellow mosaic on papaya plants in Bengkulu Province. This information is important in developing appropriate control measures that would prevent the spread of the virus to another area where the disease is not yet present.

\section{MATERIALS AND METHODS}

Research Site. A field survey was conducted from January to October 2019 at Rejang Lebong, Kepahiang, Bengkulu Tengah, and Seluma, Bengkulu Province (Figure 1). Virus detection was carried out in Laboratory of Genetics and Biotechnology, Department of Biology, Faculty of Mathematics and Natural Sciences, University of Bengkulu.

Sample Collection. Leaf samples were collected from the plants aged 8-12 months after planting. Samples were taken with purposive-random sampling according to the virus infection symptom. Papaya leaf samples showing typical of virus infection such as yellow mosaic, leaf curling, smaller leaflet, and stunting were collected from several papaya producing area in Bengkulu Province (Figure 1). The observation was conducted directly in the field with a $300-800 \mathrm{~m}^{2}$ area. The disease incidence was determined by counting the number of plants that show the symptoms from $30 \%$ of the plant population. Three typical symptomatic samples were taken for each location. The total number were 21 samples. Leaf samples were placed in plastics bags and carried to the laboratory for virus detection.

\section{RNA Virus Detection by RT-PCR analysis.}

Detection of RNA viruses by the Reverse transcriptionpolymerase chain reaction (RT-PCR) using a pair of primers specific to the Papaya ringspot virus (PRSV) and universal primers for Potyvirus.

Total RNA Extraction. We extracted total RNA from $0,1 \mathrm{~g}$ symptomatic leaves using Promega RNA extraction kit according to protocol provided by the manufactures (Promega, USA). The total RNA extract was stored at $-20{ }^{\circ} \mathrm{C}$ for further used.

Synthesis of $c D N A$. The reverse transcription reaction was carried out with a total reaction consisting of $1 \mu 1$ of total RNA, $1 \mu \mathrm{L}$ of Oligo d(T) $50 \mu \mathrm{M}, 1 \mu \mathrm{L}$ of dNTP $\operatorname{mix} 10 \mathrm{mM}$, and $16 \mu \mathrm{L}$ nuclease free water. The mix incubated at $65^{\circ} \mathrm{C}$ for $5 \mathrm{~min}$ on waterbath, then chilled

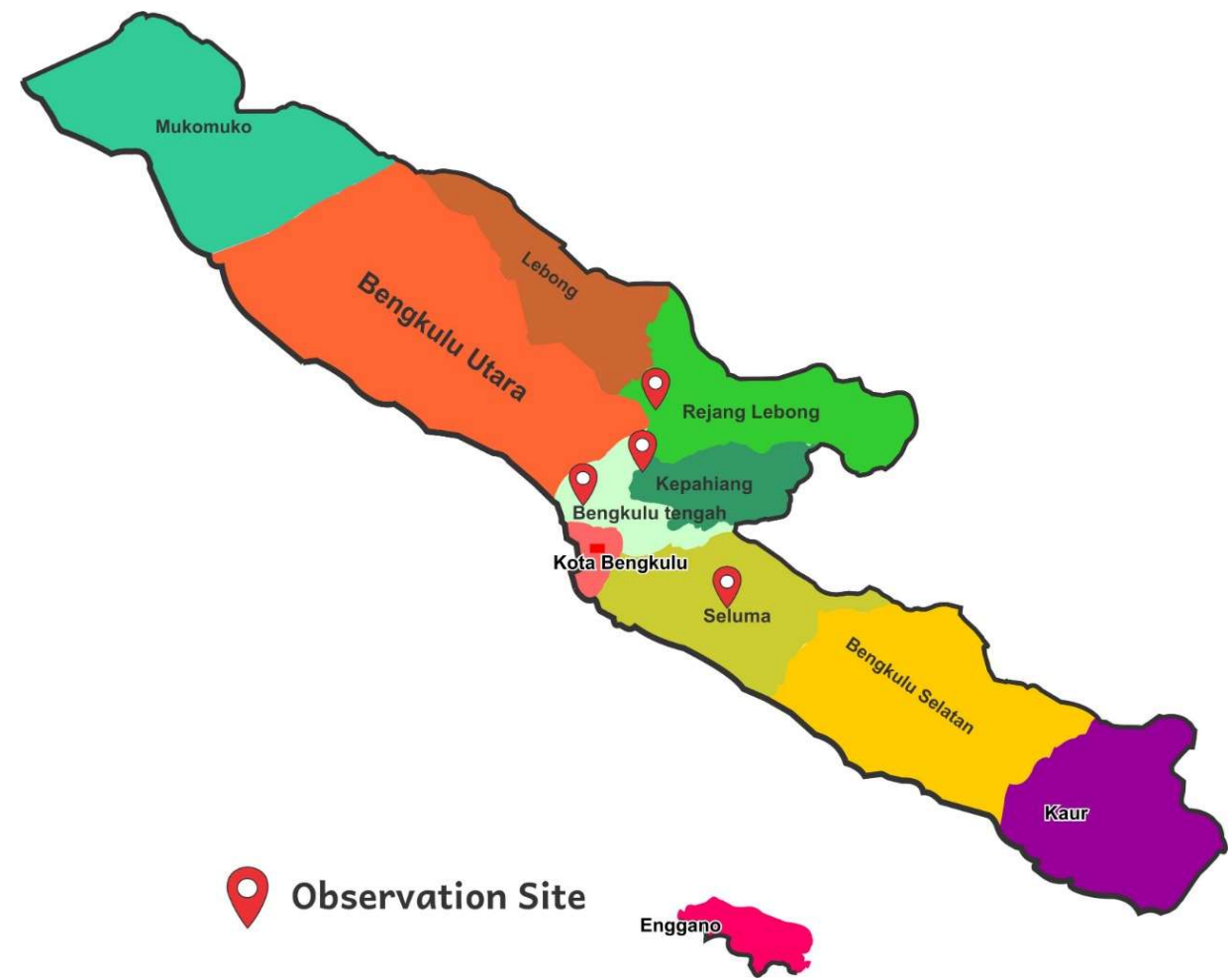

Figure 1. Sampling location in Bengkulu to collect papaya-infected virus; Rejang Lebong, Kepahiang, Bengkulu Tengah and Seluma District. 
on ice at least $1 \mathrm{~min}$. Then, added $2 \mu \mathrm{L}$ of $10 \times$ reaction buffer (NZY, Smobio), $1 \mu 1$ of ribonuclease inhibitor (NZY, Smobio), $1 \mu \mathrm{L}$ of reverse transcriptase (200 units). Reverse transcription with total volume $20 \mu \mathrm{L}$, then mixed gently and, incubate at $50{ }^{\circ} \mathrm{C}$ for $30 \mathrm{~min}$, then inactivated the reaction by heating at $85{ }^{\circ} \mathrm{C}$ for 5 min. cDNA was stored at $-20{ }^{\circ} \mathrm{C}$ for further used.

DNA Amplification for PRSV. The cDNA amplification was carry out by using specific primer for PRSV, PRSV326 (5' -TCGTGCCACTCAATCACAAT3GTCCA-3') and PRSV800 (5'GTTACTGACACTGCCGTCCA-3') (Mohammed et al., 2012). PCR reactions were prepared in $25 \mu \mathrm{L}$ total volume, containing go taq green master mix $(2 \times)$ (Thermo Fisher Scientific, Waltham, MA, USA, $10 \mathrm{mM}$ each primer, $1 \mu \mathrm{L}$ cDNA template, and $\mathrm{ddH}_{2} \mathrm{O}$. The amplification was performed in SimpliAmp thermal cycles machine (Fisher Scientific, US) with $5 \mathrm{~min}$ at $94{ }^{\circ} \mathrm{C}$ for pre-denaturation, followed by 35 cycles of denaturation $\left(1 \mathrm{~min}\right.$ at $\left.94{ }^{\circ} \mathrm{C}\right)$, annealing $(1 \mathrm{~min}$ at $59^{\circ} \mathrm{C}$ ), and extension $\left(1 \mathrm{~min}\right.$ at $\left.72^{\circ} \mathrm{C}\right)$. The last cycles were followed by $72{ }^{\circ} \mathrm{C}$ for $10 \mathrm{~min}$ and decreased at $4{ }^{\circ} \mathrm{C}$.

DNA Amplification for Potyvirus. The cDNA amplification was carry out by using universal primer for Potyvirus, namely Poty MJ-1 (5'ATGGTHTGGTGTGYATHGARAAYGG-3') and PotyMJ-2 (5'-TGCTGCKGCYTTCATYTG-3') to amplification coat protein of Potyvirus with target 320 bp (Marie-Jeanne et al., 2000). PCR reactions were prepared in $25 \mu \mathrm{L}$ total volume, containing go-taq green master mix $(2 \times)$ (Thermo Fisher Scientific, Waltham, MA, USA), $10 \mathrm{mM}$ each primer, $1 \mu \mathrm{L}$ cDNA template, and $\mathrm{ddH}_{2} \mathrm{O}$. The amplification was performed in SimpliAmp thermal cycles machine (Fisher Scientific, US) with $5 \mathrm{~min}$ at $94^{\circ} \mathrm{C}$ for pre-denaturation for $3 \mathrm{~min}$, followed by 45 cycles of denaturation $\left(30 \mathrm{sec}\right.$ at $\left.96^{\circ} \mathrm{C}\right)$, annealing $\left(1 \mathrm{~min}\right.$ at $\left.61{ }^{\circ} \mathrm{C}\right)$, and extension $(2 \mathrm{~min}$ at $72{ }^{\circ} \mathrm{C}$ ). The last cycles were followed by $72{ }^{\circ} \mathrm{C}$ for $10 \mathrm{~min}$ and decreased at $4{ }^{\circ} \mathrm{C}$.

\section{DNA Virus Detection by PCR Analysis.}

Total DNA Extraction. For the detection of DNA virus, we extracted total DNA from symptomatic leaves according to the method of Doyle \& Doyle (1990) with minor modification. Leaf tissue was ground in sterile mortar in liquid nitrogen and then $500 \mu \mathrm{L}$ extraction buffer added to the leaf powder. The extraction buffer contained $100 \mathrm{mM}$ Tris $\mathrm{pH}$ 8.0, $1.4 \mathrm{mM} \mathrm{NaCl}, 20 \mathrm{mM}$ EDTA pH 8 and $1 \%(\mathrm{v} / \mathrm{v}) \beta$-mercaptoethanol. The extraction buffer was autoclaved, and $2 \%(\mathrm{v} / \mathrm{v})$ polyvinylpyrrolidone (PVP) and 2\% CTAB were added immediately before use. After grinding, $500 \mu \mathrm{L}$ aliquots were transferred to a $2 \mathrm{~mL}$ microtube and incubate 60 minutes at $65{ }^{\circ} \mathrm{C}$ with gentle mixing to avoid the homogenate's aggregation. The extract added $500 \mu \mathrm{L}$ of chloroform: isoamyl alcohol (24:1), and the mixture was vortexed thoroughly. Then the microtube centrifuged in high speed mini-centrifuge (Biosan, Riga Latvia) for $15 \mathrm{~min}$ at 13,000 rpm. The supernatant was then transferred to a new tube, and protein precipitated by adding isopropanol $2 / 3 \times$ volume of supernatant and centrifuged in high speed mini-centrifuge (Biosan, Riga Latvia) for $10 \mathrm{~min}$ at $12,000 \mathrm{rpm}$. The pellet was washed with ethanol $70 \%(\mathrm{v} / \mathrm{v})$ and centrifuged in high speed mini-centrifuge (Biosan, Riga Latvia) for $5 \mathrm{~min}$ at $8000 \mathrm{rpm}$. The pellet was dried and resuspended by $100 \mu \mathrm{L}$ nuclease-free water. This total DNA extract was stored at $-20{ }^{\circ} \mathrm{C}$ for further use.

DNA Amplification. The Begomovirus genome was amplified by the PCR technique using a universal primer for transcriptional activator protein (TrAp) and replication-associated protein (Rep) gene of Begomovirus SPG1 (5'CCCCKGTGCGWRAATCCAT-3') and SPG2 (5'ATCCVAAYWTYCAGGGAGCTAA-3') (Li et al., 2004). PCR reactions were prepared in $25 \mu \mathrm{L}$ total volume, containing go taq green master mix $(2 \times)$ (Thermo Fisher Scientific, Waltham, MA, USA), $10 \mathrm{mM}$ each primer, $1 \mu \mathrm{L}$ DNA template, and ddH2O. The amplification was performed in SimpliAmp thermal cycles (Fisher Scientific, US) with 5 min at $94{ }^{\circ} \mathrm{C}$ for pre-heating, followed by 30 cycles of denaturation $\left(1 \mathrm{~min}\right.$ at $\left.94{ }^{\circ} \mathrm{C}\right)$, annealing $\left(1 \mathrm{~min}\right.$ at $\left.59{ }^{\circ} \mathrm{C}\right)$, and extension $\left(1 \mathrm{~min}\right.$ at $\left.72{ }^{\circ} \mathrm{C}\right)$. The last cycles were followed by $72{ }^{\circ} \mathrm{C}$ for $10 \mathrm{~min}$ and decreased at $4{ }^{\circ} \mathrm{C}$.

DNA Visualization by Electrophoresis. DNA Amplification products were analyzed on 1\% agarose gel electrophoresis in $0.5 \mathrm{X}$ TBE buffer containing nucleic acid staining with Ethidium bromide at 50 volt in $50 \mathrm{~min}$. Agarose gel electrophoresis was used to visualize the PCR products. Furthermore, visualization of the agarose gel on Gel documentation (GelDoc, Axygen) and the results of the images were stored on a computer. 


\section{RESULTS AND DISCUSSION}

Disease Symptoms. Infected plants were recognized in the field based on visual symptoms. The symptom dominantly found in each district can be seen in Table 1 . Five main symptoms of yellow mosaic disease in the field were observed, i.e. 1) yellowing; 2) yellowing with the brown spot; 3) leaf malformation (Figure 2). The most symptom found in Rejang Lebong and Kepahiang District was yellowing and leaf malformation. The symptoms seen in Bengkulu Tengah and Seluma District were yellow with dark spots. This type of symptoms yellowing and yellowing with brown spot had not been reported as typical symptoms of papaya's yellowing disease in Indonesia.

Disease Incidence. The incidence of yellow mosaic disease was very high, i.e. $42.75 \%$ to $100 \%$ on calina and $0 \%$ on local varieties in 7 growing areas located at Rejang Lebong, Kepahiang, Bengkulu Tengah, and Seluma District (Table 1). Begomovirus is a member of the family Geminiviridae, which is the largest group of plant viruses. Geminiviruses are subdivided into four genera based on host range, insect vector, and genome organization. The genus Begomovirus (Subgroup III) consists of whiteflies' viruses to infect dicotyledonous plants with a monopartite or bipartite arrangement (Fauquet \& Stanley, 2003). In Indonesia, Begomovirus was observed infecting pepper (Rusli et al., 1999, Trisno et al., 2009); tobacco (Hidayat et al., 2002, Trisno et al., 2014); Ageratum conyzoides (Haerani \& Hidayat, 2003); eggplant (Kintasari et al., 2013); cucumber
(Septariani et al., 2014, Wiratama et al., 2015); yard long bean (Nurulita et al., 2015); and soybean (Rahim et al., 2015; Sutrawati et al., 2020). Sulandari (2004) reported that Begomovirus on pepper was named Pepper yellow leaf curl virus (PYLCV) and characterization of the partial genomic sequence of the PYLCV was reported by Hidayat et al. (2006). Begomovirus on cucumber was reported by Wiratama et al. (2015) was named as Squash leaf curl China virus (SLCCNV). Begomovirus has been reported to infect papaya in India (Reddy et al., 2010) and China (Shen et al., 2014).

Identification of the Causal Agent. RT-PCR by using a pair of specific primers to PRSV and universal primers for Potyvirus showed negative results (data not shown), indicating that the causal virus (es) were not PRSV or other Potyvirus. However, by using universal primer for Begomovirus the DNA fragments with size $\sim 900$ bp were successfully amplified from samples showing yellow with brown spot (Figure 3, lane 1-2), yellow mosaic (Figure 3 lane 3, 4, 5) from all locations, but no DNA amplified from samples showing stunting and leaf malformation (Figure 3, lane 7). This is indicating that Begomovirus with severe yellow mosaic disease and yellow with papaya's brown spot disease in Bengkulu.

Two types of Begomovirus in papaya that have been reported in China; Papaya leaf curl China virus (PalCuCNV, Acc. No. AJ558122) and Papaya leaf curl Guangdong virus (PalCuGDV, Acc. No. AJ558123) (Tennant et al., 2007). The other member of Begomovirus, Papaya leaf curl virus (PalCV) have

Table 1. Symptoms and disease incidence of yellowing disease on papaya in Bengkulu

\begin{tabular}{|c|c|c|c|c|}
\hline \multicolumn{2}{|c|}{ Location } & \multirow{2}{*}{ Variety } & \multirow{2}{*}{ Symptom } & \multirow{2}{*}{$\begin{array}{c}\text { Disease incidence } \\
(\%)^{*}\end{array}$} \\
\hline District & Sub district & & & \\
\hline \multirow[t]{5}{*}{ Rejang Lebong } & Curup & Calina & $\begin{array}{l}\text { Yellow mosaic, yellowing, } \\
\text { leaf malformation }\end{array}$ & $100(66 / 66)$ \\
\hline & & Local & No symptom & $0(0 / 3)$ \\
\hline & Curup Selatan & Calina & $\begin{array}{l}\text { Yellow mosaic, leaf } \\
\text { malformation }\end{array}$ & $44.70(114 / 255)$ \\
\hline & & Local & No symptom & $0(0 / 22)$ \\
\hline & Curup Selatan & Calina & Yellow mosaic systemic & $100(56 / 56)$ \\
\hline Bengkulu Tengah & Taba Penanjung & Calina & Yellow with dark spot & $100(116 / 116)$ \\
\hline \multirow[t]{2}{*}{ Kepahiang } & Kepahiang & Calina & $\begin{array}{l}\text { Yellow mosaic, leaf } \\
\text { malformation }\end{array}$ & $42.75(59 / 138)$ \\
\hline & & Local & No symptom & $0(0 / 22)$ \\
\hline Seluma & Sukaraja & Calina & Yellow with dark spot & $100(400 / 400)$ \\
\hline
\end{tabular}

*Number in parenthesis showed total infected plants/total plants observed 
been reported in papaya plants in Taiwan (Chang et al., 2007) and India (Reddy et al., 2010) with symptoms of infection in the form of curly leaves, twisted petiole, leaf enation, and stunting, produce smaller fruit and will die prematurely. Other research in China shows the symptoms of curling and yellowing of the leaf bones in papaya plants caused by Ageratum yellow vein virus (AYVV) associated with a new betasatelit that infects papaya, which is then proposed as Papaya leaf curl China beta satellite virus (Shen et al., 2014). A new
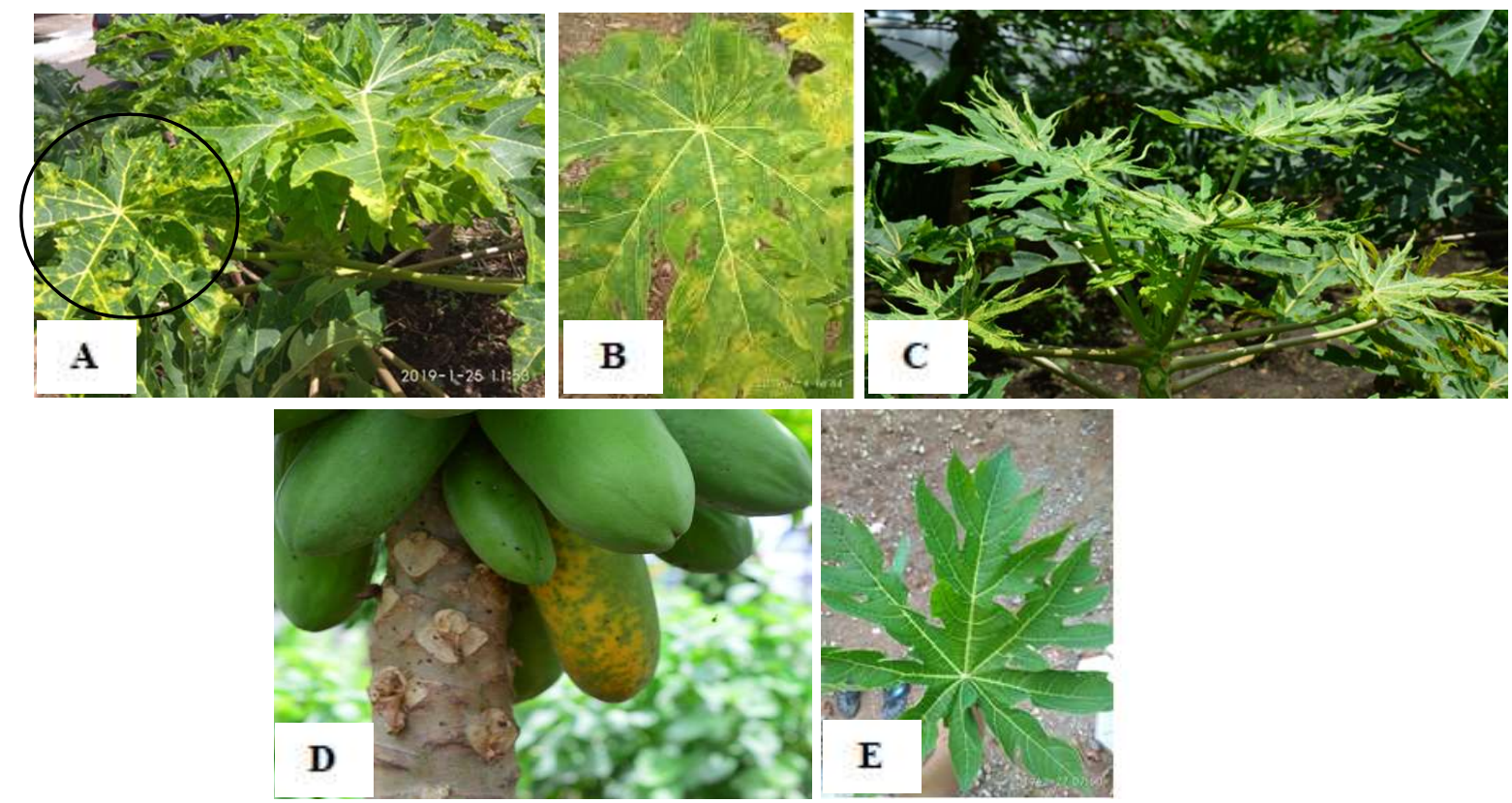

Figure 2. Symptoms of yellowing disease on papaya. (A) Yellowing; (B) Yellowing with brown spot; (C) Leaf malformation; (D) Green spot on fruit; (E) Healthy papaya leaves.
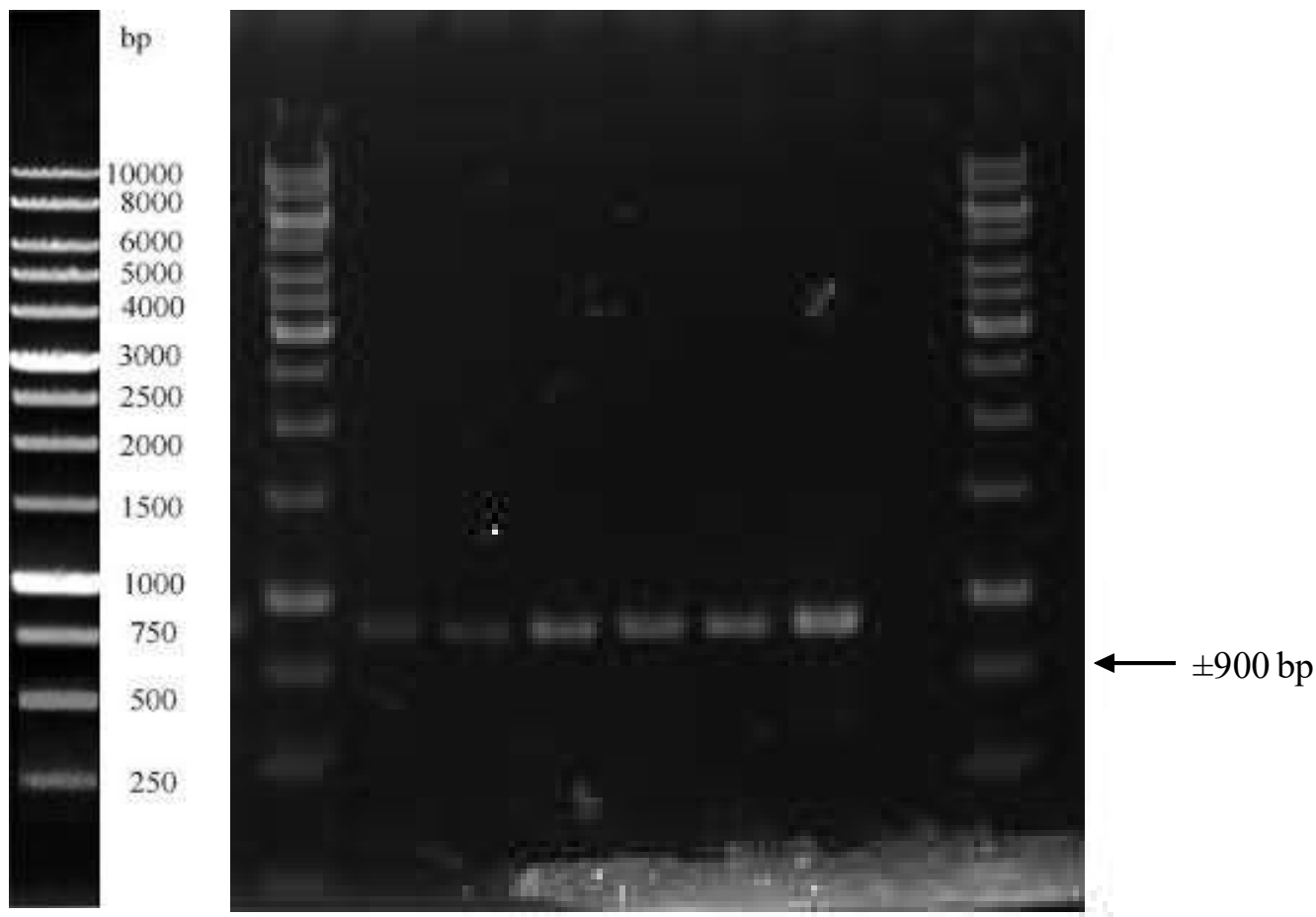

Figure 3. Visualization of Begomovirus amplification from leaf samples using universal primers SPG1/SPG2 on 1\% agarose gel. M, 1000 bp DNA Ladder (Thermo Scientific, US); lanes 1-2, Seluma samples; 3, Bengkulu Tengah samples; 4, Rejang Lebong samples; 5, Kepahiang samples; 6, Positive control (Chilli); 7, Rejang Lebong samples. 
Begomovirus Papaya leaf curl virus and its associated betasatellite infecting papaya in India, this virus considered as a new species of Begomovirus with propose the name Papaya yellow leaf curl virus according to ICTV guidelines for new Begomovirus species (Nehra et al., 2019).

Symptoms on papaya leaves such as yellowing and yellowing with brown spot had not been reported as typical symptoms of papaya's yellowing disease in Indonesia. To the author's knowledge, Begomovirus infection on papaya has never been reported in Indonesia. This finding is the first report of Begomovirus infection in papaya in Indonesia.

Molecular detection confirmed the association of Begomovirus in the yellow mosaic disease of papaya in Bengkulu. Further study on identifying virus species, host range, insect transmission, and disease spread is significant for understanding disease development and controlling the disease. In addition, in the future it is necessary to identify the causal of stunting and leaf malformation on papaya found in the fields which may become a potential threat on papaya production in Indonesia.

\section{CONCLUSION}

Severe systemic yellow mosaic on papaya leaves is associated with Begomovirus infection, while the causal of leaf malformation and stunting is unknown yet. This work is the first report of Begomovirus infected papaya in Indonesia. It is necessary to study the existence of Begomovirus infecting papaya on other area, their characterization, biological and genetic variabilities and integrated management strategies to mitigate this virus infection and distribution in Indonesia.

\section{ACKNOWLEDGMENTS}

The author would like to thank the Research and Community Service Office at University of Bengkulu for funding this research with a contract number: 2175/ UN30.15/LT/2019.

\section{REFERENCES}

Chang LS, Lee YS, Su HJ, \& Hung TH. 2003. First report of papaya leaf curl virus infecting papaya plants in Taiwan. Plant Dis. 87(2): 204.

Doyle JJ \& Doyle JL. 1990. Isolation of plant DNA from fresh tissue. Focus. 12(1): 13-15.
Fauquet CM \& Stanley J. 2003. Geminivirus classification and nomenclature: progress and problems. Ann. Appl. Biol. 142(2): 165-189.

Haerani \& Hidayat SH. 2003. Geminivirus penyebab penyakit kuning pada babadotan (Ageratum conyzoides): deteksi molekuler dan studi penularan pada beberapa tanaman Solanaceae. J. Fitopatol. Indones. 7(2): 65-70.

Harmiyati T, Hidayat SH, \& Adnan AM. 2015. Deteksi dan respons lima varietas pepaya terhadap tiga isolat Papaya ringspot virus (PRSV). J. AgroBiogen. 11(3): 87-94.

Hidayat SH, Mulyati S, Kadir M, Sulandari S, \& Aidawati N. 2002. Tobacco leaf curl virus from Indonesia: its detection and host range study. J. Agrik. 13: 157-161.

Hidayat SH, Chatchawankanpanich O, Rusli E, \& Aidawati N. 2006. Begomovirus associated with Pepper yellow leaf curl disease in West Jawa, Indonesia. J. Microbiol. Indones. 11(2): 87-90.

Hidayat SH, Nurulita S, \& Wiyono S. 2013. Infeksi Papaya ringspot virus pada tanaman pepaya di Provinsi Nanggroe Aceh Darussalam. J. Fitopatol. Indones. 8(6): 184-187.

Hidayat S, Nurulita S, \& Wiyono S. 2012. Temuan penyakit baru infeksi papaya ringspot virus pada tanaman pepaya di Nangroe Aceh Darussalam. J. Fitopatol. Indones. 8(6): 184-187.

Kintasari T, Septariani DWN, Sulandari S, \& Hidayat SH. 2013. Tomato yellow leaf curl Kanchanaburi virus penyebab penyakit mosaik kuning pada tanaman terung di Jawa. J. Fitopatol. Indones. 9(4): 127-131.

Li R, Salih S, \& Hurtt S. 2004. Detection of geminiviruses in sweetpotato by polymerase chain reaction. Plant Dis. 88(12): 1347-1351.

Listihani, Damayanti TA, Hidayat SH, \& Wiyono S. 2018. Karakterisasi molekuler Papaya ringspot virus tipe $\mathrm{P}$ pada tanaman mentimun di Jawa. J. Fitopatol. Indones. 14(3): 75-83.

Marie-Jeanne V, Ioos R, Peyre J, Alliot B, \& Signoret P. 2000. Differentiation of Poaceae Potyviruses by reverse transcription polymerase chain reaction and restriction analysis. J. Phytopathol. 148(3): 141-151. 
Mohammed H, Manglli A, Zicca S, El Hussein A, Mohamed M, \& Tomassoli L. 2012. First report of Papaya ringspot virus in pumpkin in Sudan. New Dis. Rep. 26: 26.

Nehra C, Marwal A, Verma RK, Mishra M, Sharma P, \& Gaur RK. 2019. Papaya yellow leaf curl virus: A newly identified Begomovirus infecting Carica papaya $\mathrm{L}$. from the Indian Subcontinent. J. Hortic. Sci. Biotechnol. 94(4): 475-480.

Nuhantoro I. 2017. Konstruksi pelacak DNA Papaya ringspot virus berdasarkan gen helper component untuk metode deteksi hibridisasi asam nukleat. Tesis. IPB University. Bogor.

Nurulita S, Hidayat SH, Mutaqin KH, \& Thomas J. 2015. Molecular characterization of Begomovirus infecting yard long bean (Vigna unguiculata subsp. sesquipedalis L.) in Java, Indonesia. BIOTROPIA. 22(1): 53-60.

Rahim YF, Damayanti TA, \& Ghulamahdi M. 2015. Deteksi virus yang menginfeksi kedelai di Jawa. J. Fitopatol. Indones. 11(2): 59-67.

Reddy MK, Venkataravanappa V, Madhuvanthi B, \& Jalali S. 2010. Molecular characterization of Begomoviruses associated with papaya leaf curl disease in India. Acta Hortic. 851: 465-472.

Rusli ES, Hidayat SH, Suseno R, \& Tjahjono B. 1999. Virus Gemini pada cabai: variasi gejala dan studi cara penularan. Bulletin HPT. 11(1): 26-31.

Saxena S, Hallan V, Singh BP, \& Sane PV. 1998. Nucleotide sequence and intergeminiviral homologies of the DNA-A of Papaya leaf curl geminvirus from India. Biochem. Mol. Biol. Int. 45(1): 101-113.

Septariani DN, Hidayat SH, \& Nurhayati E. 2014. Identifikasi penyebab penyakit daun keriting kuning pada tanaman mentimun. J. HPT Tropika. 14(1): 80-86.
Shen W, Tuo D, Yang Y, Yan P, Li X, \& Zhou P. 2014. First report of Ageratum yellow vein virus associated with a new betasatellite infecting Carica papaya in China. J. Plant Pathol. 96(3): 603-611.

Singh-Pant P, Pant P, Mukherjee SK, \& MazumdarLeighton S. 2012. Spatial and temporal diversity of begomoviral complexes in papayas with leaf curl disease. Arch. Virol. 157(7): 1217-1232.

Sulandari S. 2004. Karakterisasi biologi, serologi dan analisis sidik jari DNA virus penyebab penyakit daun keriting kuning cabai. Disertasi. Institut Pertanian Bogor. Bogor.

Sutrawati M, Hidayat SH, Suastika G, Sukarno BPW, \& Nurmansyah A. 2020. Yellow mosaic disease on soybean. J. Fitopatol. Indones. 16(1): 30-36.

Tennant PF, Fermin GA, \& Roye ME. 2007. Viruses infecting papaya (Carica papaya L.): etiology, pathogenesis and molecular biology. Plant Viruses. 1(2): 178-188.

Trisno J, Hidayat SH, Habazar T, Manti I, \& Jamsari. 2009. Detection and sequence diversity of Begomovirus associated with yellow leaf curl disease of pepper (Capsicum annuum) in West Sumatera, Indonesia. Microbiology. 3(2): 56-61.

Trisno J, Rifqah RA, \& Martinius. 2014. Leaf curl disease of tobacco in West Sumatera. J. Fitopatol. Indones. 10(6): 210-213.

Wiratama IDMP, Wirya GNAS, Adnyani NNP, Nyana IDN, \& Suastika G. 2015. Laporan pertama infeksi Begomovirus pada tanaman mentimun di Bali. J. Fitopatol. Indones. 11(5): 175-178. 